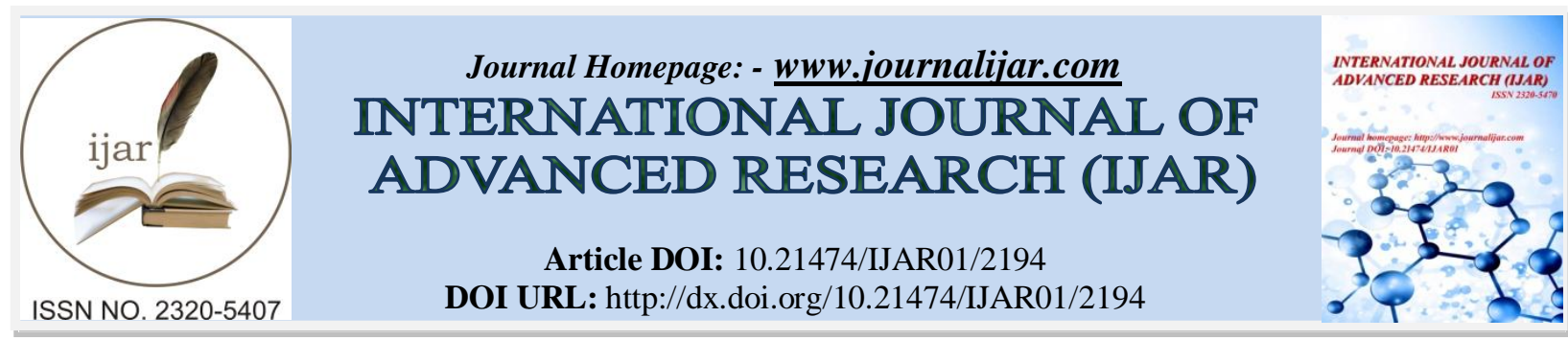

RESEARCH ARTICLE

\title{
PERSPECTIVE OF PROGRESSIVE LAW TOWARDS THE COMPANY'S SOCIAL RESPONSIBILITY AND ENVIRONMENT IN REALIZATION OF GREEN DEVELOPMENT IN SOUTHEAST SULAWESI.
}

Muhammad Jufri ${ }^{1}$ and Deity Yuningsih ${ }^{2}$.

1. Senior Professor at Faculty of Law, Halu Oleo University, Southeast Sulawesi, Indonesia.

2. Lecturer at Faculty of Law, Halu Oleo University, Southeast Sulawesi, Indonesia.

\section{Manuscript Info}

Manuscript History

Received: 27 September 2016

Final Accepted: 30 October 2016

Published: November 2016

Key words:-

social responsibility, and legal certainty.

\section{Abstract}

The Province of Southeast Sulawesi is located in Indonesia, it has potential mining resources. There are many mining companies conducting exploration mining in this province. Unfortunately, the existence of those companies have not had a positive impact in social welfare for province of Southeast Sulawesi's society. On the contrary, the companies do damage to environment. Whereas, they have a social responsibility and to keep environmental suistainability. It is stated by article 74 of Act of No. 40 of 2007 on Limited Company. It is very urgent to do research on legal principle and legal substance in Act of No. 40 of 2007. Does legal principle and legal substance in this act regulate to realization green development as a norm of conduct for mining companies? And how to implementation. This research uses the type of empirical and normative legal. The result of this research shows that regulation on company's social responsibility and environment in realization of green development in Indonesia, it still diverses in various laws. This causes company's social responsibility and environment in realization of green development, it yet has not oriented for suistainable green development.

Copy Right, IJAR, 2016,. All rights reserved.

\section{Introduction:-}

Preservation of the environment is a dream for every human being, both individually and socially in the the earth, so that environmental management requires for responsibility of good governance and public participation, as defined in Article 70 (3) of the Act No. 32 of 2009 on the Protection and Environmental Management. Management of the environment, including natural resources become an important means to achieve prosperity and environmental quality of life of the present generation and future generations. Therefore, the environment is managed with the principle of preserving the environmental functions that are harmonious and balanced development to support the development of environmentally sustainable. In this case, there must be synergy between the management of natural resources, on the one hand, with the preservation of the environment on the other. Thus, environmental management is a systematic and integrated efforts are being made to preserve the environment and prevent pollution and/or damage to the environment.

The integration of all the elements in environmental management, is a form of environmental conservation in achievement for environmentally sustainable; be a conscious and planned effort that combines aspects of environmental, socio-cultural aspects of the environment, and economic development strategies to ensure the 
integrity of the environment and safety, capacity, welfare quality of life of the present generation and future generation. The effort is particularly important given the increasing utilization of the physical environment that tends to cause impacts and risks to the environment.

According to Jufri Dewa (2013) that weaknesses in the management of environment and natural resources may be conflict between the interests of mining land mine operators with the people because of the seizure of the mine site, in the conflict of the people who have always been victims.

The existence of the importance of Corporate Social Responsibility and Corporate Environment (Tanggung Jawab Sosial Lingkungan Perusahaan) is regulated in Article 74 of Act No. 40 In 2007, it is inspired by a paradigm in continuing to grow recently which teaches that the company as a company that conducts business activities in the midst of society, must take responsibility for the social problems faced by local communities, so that the company should have concern for the community where it was living and being. Article 74 of Act No. 40 of 2007 on Limited Liability Company (Undang-Undang PT) is not formal rules first introduced the concept of Social Responsibility and Corporate Environment in Indonesia. The use of the term is often also used the term corporate social responsibility (CSR). About three months before the Act No. 40 of 2007 was born, the Government of Indonesia has introduced the concept of Corporate Social Responsibility (CSR) through Article 15 letter b, of Act No. 25 of 2007 on Investment, which states that every investor is obliged to carry out the responsibilities of the company.

The existence of a rule of law in a legal perspective is the norm progressive legal certainty for the welfare and happiness of its legal subject, in this case the people who are around the company have a more prosperous life and still enjoy the benefits of environmental functions both as an important element in achieving happiness. Based on the reality of the existence of companies that have an impact on social life and the environment and their responsibility for the company mandated by the Act, this research was done comprehensively in the field of law with respect to the existence of the substance and legal principles contained in the legislation related with social and environmental responsibility of companies, also its implementation in counties and cities in Southeast Sulawesi.

\section{The Method of Research:-}

The research was conducted in Southeast Sulawesi, namely in Bombana and Kendari using cluster sampling. The research location is determined only as a supporter for more concentrated on the study of law is normative, namely the assessment of written law about legislation relating to social responsibility and corporate environment (Ibrahim, 2005). Therefore, the legal approach of research used is a sociological legal approach that is linked with the fact that occur in the community; legal approach is to examine the regulations concerned with legal issues being addressed; and the conceptual approach to move from doctrines that developed in the jurisprudence, so it will find the ideas and concepts of law relevant to the issues faced. Data collection techniques using the technique of literature study, observation, and interviews with informants. The analysis technique used is descriptive qualitative.

\section{The Result of Research:-}

The result of research shows that the legal regulation for social responsibility and environmental responsibility of companies nationally, stated in some legislation. The diversity of legislation becomes a difficulty in achieving legal of certainty implementation. There is legislation in its provisions explicitly mention legal obligation for any company to Social Responsibility and Corporate Environment, but there are also laws that only uses the concept of community development and empowerment programs. From a legal perspective that if there are two or more laws governing the same substance, but by using the phrase or words that differ will very likely give rise to problems of conflict of legal norms. Raises the issue of legislation which will be applied and legal norms which can give assurance in the implementation of that legal obligation on Social Responsibility and Corporate Environment optimally beneficial to society and the environment.

Based on the empirical facts about the implementation of each company for the obligations of Social Responsibility and Corporate Environment in Southeast Sulawesi, it has not been implemented well because not all companies understand the concept of Social Responsibility Environmental properly. Companies are more inclined to the implementation of the program in the sphere of social aspects rather than aspects on preservation of environmental functions. Environmental damage caused by industry is a thing that must be addressed, because environmental degradation has a significant impact on human survival itself. In this case the industrial management balanced with environmental management, so that the problems of environmental damage by the industry can be minimized. 
Also researches Pfleiger et al. (Ja'far, 2005) indicate that good environmental management can avoid claims of society and government as well as improve the quality of the products that will ultimately be able to increase the economic benefits. Similarly, the views Ferreira (Ja'far, 2004) that the issue of environmental conservation is the duty of individuals, governments, and enterprises. As part of the social order, the company should report its environmental management in the annual report. However, the level of implementation is not maximized, like at the planning stage of management environment, the use of the environment, the stages of its control environment, as well as on the stages of preservation of the environment. Damage towards the environment in Southeast Sulawesi, especially in the regent of Bombana, it has occurred in the area around the company, as well as the results of research in Jufri Dewa (2013) that the company conducting mineral mining gold have an impact on (1) Damage to the forest ecology in the form of a reduction in water flow of the river and land, floods and landslides; (2) the impact on agriculture, in the form of source/low water flow and causes drought in rice fields of society; (3) the impact of the decline in water quality, because the content of mercury in the water source of the river reached 0.98 is much larger than the tolerance limit of $0.002 \mathrm{mg} /$ liter of water; (4) the impact on the socio-cultural, that the social gap between the newcomers and the people living around the mining area due to lack of accessible works in the mining company; (5) the impact on the economy, a decrease in the incomes of the original farmers, no longer able to farm because of the lack of water flowing into paddy fields due to be banked and used for the processing of gold; and (6) the impact on the health of the environment, such as the unwillingness of clean water, disease patterns and prevalence rate in the presence of a gold mineral mining activities, as well as the right to a good environment and healthy as part of human rights are not fulfilled again.

The condition damages for functions environmental, socio-cultural, economic and community shows that the company does not have contributions concern the good of society (social) and the natural environment around the company, even though the legislation has required the obligation of each company to contribute to society and the local environment called social responsibility and environmental companies. Comprehensively, it can not be denied that legal norms factor also plays an important role, so that the law not implemented towards obligations social and environmental responsibility for every company well, because:

1. Regulation on Social Responsibility and Corporate Environment still very diverse and scattered in several legislations. Companies that do not have a shared understanding of the legal basis to be used in implementing the obligations of social responsibility program and the Corporate Environment (TJSLP/Tanggung Jawab Sosial Lingkungan Perusahaan in Indonesia Language). The realization of CSR should be more focused use of the legal basis contained in the Act No. 40 of 2007 on Limited Company (Undang-Undang PT in Indonesia Language) is not against Law No. 4 of 2009 on Mineral and Coal Mining (Mining Law), Act No. 21 of 2014 on Geothermal, or any other laws. It was in consideration of the principle of law lex specialis, that the legislation of a special nature will rule out the laws of a general nature.

2. Not all local authorities have a Local Regulation on Social Responsibility and Corporate Environment. Implementation of TJSLP in the local government areas that do not have legislation on TJSLP causes consultation and communication of the government can not be done properly related government programs that can be synergized with the Social Responsibility and Environment at each company. The government has not made good supervision, thus allowing the implementation of the program form the Social and Environmental Responsibility to be very varied and unfocused, program activities that are repetitive or even have not been touched at all. One of the local governments that already have a Local Regulation on Social Responsibility and Corporate Environment in Southeast Sulawesi is the Local Government Kendari Kendari, namely the Regional Regulation No. 17 of 2014 on Social and Environmental Responsibility Company City Regional Kendari. It is legally constitute legal basis to follow up the contents of the regulations governing the TJSLP in the city of Kendari environmentally sustainable manner in order to run properly.

3. The absence of a clear legal basis of how much money the company should be excluded, either budgeted into the company's calculated as cost or budgeted of corporate profits.

Act of No. 47 of 2012 on Limited Liability Company Law and Government, it only emphasizes that in formulating and establish a plan of activities and budget should pay attention to decency and fairness. Reasonableness according part of the explanation is the Company's policy, which is tailored to the financial capabilities of the Company, and the potential risks that lead to social responsibility and the environment must be borne by the Company in accordance with its business activities that do not reduce the obligations as stipulated in the provisions of the legislation related the Company's business activities. Conditions such as these can provide space of multi interpretation, because it is very difficult to gauge what is a reasonable budget, and worth it objectively. Such provisions create legal uncertainty in law enforcement and has the potential subjectivity in the planning, 
implementation, and supervision, so it will greatly affect the implementation of optimalization of legal obligation on social and environmental responsibility of each company. Based on Satjipto Rahardjo's legal perspective, he is the pioneer of progressive law, states that the law is a human institution that aims to deliver the life of a just, prosperous, and make people happy. As a consequence of the law is a process of continuous (law in the making) to establish itself toward that ideal. Progressive legal criteria, such as: (1) it tries to achieve prosperity and happiness of humankind; (2) it contains the moral values of humanity; (3) dimension in the realm of practice and the realm of theory; and (4) it is critical and functional that never stopped looking at the existing of deficiencies and determine the way to fix it.

\section{Closing:-}

Laws and legislation regulating the legal obligations on Corporate Social Responsibility and Environmental companies scattered in various regulations and not all of the county or city in Southeast Sulawesi has a regulatory area of Social Responsibility and Corporate Environment, so it has not been able to provide legal certainty in achieving development environmental sustainable. It has an impact on the empirical fact that the legal obligations on Social and Environmental Responsibility Company in Southeast Sulawesi has not been implemented well. In respect of this, the local government should do a firmer legal norms related to setting up the Social and Environmental Responsibility of the right company for the realization of public welfare environmental sustainable.

\section{References:-}

1. Joachim Friedrich, Carl (2004) Legal Philoshophy In The History Perspective, Nuansa and Nusamedia, Bandung City, Indonesia.

2. Ibrahim, Johnny (2005) the Theory and Method to Normative Legal Research, Bayumedia Publishing, Surabaya City, Indonesia.

3. Marsuki, Laica (1995) SIRI' Is the Part of Legal Awareness of the People of Buginese and Macazarish, Hasanuddin University Press, Makassar City, Indonesia.

4. Dewa, Mohammed Jufri, the Analysis of Impact of Mineral Mining of Gold towards Environment Conservation, Journal of Legitime Vol. III No. 1, March, 2013.

5. Bombang, Saifullah (2008) the Nature of Justice for Poligamy; A Study for Islamic Law, Dissertation Research, School of Law, Hasanuddin University, Macassar City, Indonesia.

6. Rahardjo, Satjipto (2007) A Study for Legal of Progressive, Kompas, Jakarta City, Indonesia.

7. (2009) the Legal of Progressive, A Study for Indonesia Legal, Genta Publishing, Yogyakarta City, Indonesia. 